\title{
Optimal conditions, kinetic model and Packed Bed Reactor system for biodegradation of Linear Alkylbenzene Sulfonate by AOS-15 microorganism
}

\author{
Witawat Jangiam, Sarayut Petra \\ Burapha University, Department of Chemical Engineering, Faculty of Engineering, Chonburi, Thailand.
}

Correspondence Author: Witawat Jangiam, Burapha University, Department of Chemical Engineering, Faculty of Engineering, Chonburi, Thailand. E-mail: witawat@eng.buu.ac.th

Received date: 22 June 2018, Accepted date: 16 August 2018, Online date: 8 September 2018

Copyright: (C) 2018 Witawat Jangiam, Sarayut Petra. This is an open-access article distributed under the terms of the Creative Commons Attribution License, which permits unrestricted use, distribution, and reproduction in any medium, provided the original author and source are credited.

\begin{abstract}
BACKGROUNG: Linear alkylbenzene sulfonate (LAS), an anionic surfactant, is the most widely used ingredient in synthetic detergents, and is thus released to the environment in large quantities. Effective methods of treatment which can degrade LAS are need of the hour. OBJECTIVE: The aim of the present study is to develop a bioreactor for complete degradation of LAS using immobilized cells of AOS-15 microorganism isolated from the wastewater treatment plant of Lion Corporation Limited (Thailand) and alginate-entrapped cells of AOS-15 were used for degradation of LAS in a Packed Bed Reactor (PBR). RESULT: The batch shake flask study showed the suitable condition of AOS-15 free cell to biodegrade $3 \mathrm{~g} / \mathrm{L}$ LAS is $2.1 \mathrm{~g}$ cell mass. Moreover, we studied LAS initial concentration and $\mathrm{pH}$ on the degradation of LAS of free and calcium alginate immobilized cells. The results showed that LAS degradation was significantly improved using immobilized cells compared to that of free cells, where $2.1 \mathrm{~g}$ of immobilized cell at pH7 totally removed $100 \mathrm{ml}$ of $3 \mathrm{~g} / \mathrm{L}$ LAS within 48 hours. The efficiency of LAS degradation was further monitored in batches and continuous bioreactor experiments. The kinetics of biodegradation was optimized at the best conditions of free cell experiment. Simultaneously, kinetics equation of LAS biodegradation in batch at LAS concentration of 1.5-5 g/L is: Further, on Packed Bed Reactor (PBR) system, the immobilized microorganism was placed in the PBR column and the synthetic medium with LAS was pumped into it at $0.06 \mathrm{ml} / \mathrm{minute}$. LAS could be degraded by AOS-15 microorganisms up to $80-96 \%$ in 80 hours of continuous study. CONCLUSION: The LAS biodegradation by AOS-15 microorganisms in a continuous flow system of PBR showed the efficiency of biodegradation. Our experiment showed that the PBR system had a high efficiency of LAS degradation, i.e., in 0-84 h, the biodegradation rate ranged from 80$96 \%$.
\end{abstract}

Key words: Biodegradation, surfactant, linear alkylbenzene sulfonate, kinetic equation, packed bed reactor.

\section{INTRODUCTION}

Surfactants or "SURFaceACTiveAgeNTs" are organic compounds, which contain both hydrophobic groups, including saturated hydrocarbons, natural fatty acids, paraffin, and hydrophilic groups that may be polar or non-polar. When surfactants are put into water, the hydrophobic group is less reactive than the hydrophilic group, thus imparting emulsification, foaming, and particle suspension [1]. About 7.2 million tons of synthetic surfactants are produced in the world annually [2]. They constitute a major ingredient of synthetic detergents for domestic and industrial applications, such as personal care products, cosmetics, food packaging, petroleum production, pharmaceuticals, etc. Surfactants are of four types: cationic, anionic, non-ionic, and amphoteric. Anionic surfactants, such as sodium dodecyl sulfate (SDS), linear alkylbenzene sulfonate (LAS), alpha olefin sulfonate (AOS), alcohol ester sulfate (AES), and fatty alcohol sulfate (FAS) are the most widely used primary surfactants [2]. About, 18 million tons of LAS was globally consumed in 2003 compared with 9, 1.7, 0.5, 0.1, and 2.4 million tons of soap, non-ionic, cationic, amphoteric, and other surfactants, respectively [3].LAS is a mixture of aromatic rings, sulfonated at the p-position, linked to the linear alkyl chain (ranging from 10-14 carbon atoms) at any position except the terminal ones [4]. Wastewater from household products and other cleaning processes contain an increasing amount of LAS. The LAS contamination majorly impacts the ecosystem, especially, the aquatic life [5].

Biological processes play an important role in the removal of contaminants and take advantage of the catabolic versatility of microorganisms to degrade such compounds. Pseudomonas putida degrades phenol into cell mass, carbon dioxide and other less toxic substances, such as benzoate and acetate [4,6]. Similarly, Paracoccus sp. can be used to biodegrade pyridine, which is a carcinogen [3]. However, biological treatment can be used to treat wastewater containing LAS, due to its low operation costs as compared to chemical treatment of wastewater. Many chemical substances can be degraded by microorganisms under aerobic conditions. Previous research on LAS and surfactants biodegradation by microorganisms include studies of pure culture or mixed culture bacteria, kinetics of degradation, and use of certain techniques, such as ultrasound irradiation, immobilization on different supports, application of continuous systems, such as up-flow anaerobic sludge blanked (UASB), fluidized bed bioreactor, anaerobic membrane bioreactor etc., to improve the effectiveness of degradation [1,4-11]

The first discovery for the highly powerful LAS-degrading bacteria, AOS-15, was reported and conducted in our laboratory [5]. In that study, we found the AOS-15 microorganism which was isolated from the wastewater treatment plant of Lion Corporation (Thailand) Limited. Thus, in this study, important influencing factors such as cell density, initial LAS concentration and $\mathrm{pH}$ were also investigated to determine the most suitable conditions in suspended and immobilized cells that will maximum LAS biodegradation by AOS-15 microorganism which was further identified as Pseudomonassp. Additionally, the research also aimed to study the kinetic equation of batch biodegradation using the POLYMATH ${ }^{\mathrm{TM}}$ program. Moreover, packed bed reactor (PBR) with AOS-15 was used to study the efficiency of LAS biodegradation. 


\section{Methodology:}

Materials:

The study used synthetic media consisting of $420 \mathrm{mg} / \mathrm{L} \mathrm{KH} \mathrm{P}_{2}, 375 \mathrm{mg} / \mathrm{L} \mathrm{K} \mathrm{HPO}_{4}, 244 \mathrm{mg} / \mathrm{L}\left(\mathrm{NH}_{4}\right)_{2} \mathrm{SO}_{4}, 40 \mathrm{mg} / \mathrm{L} \mathrm{CaCl} \cdot 2 \mathrm{H}_{2} \mathrm{O}, 30 \mathrm{mg} / \mathrm{L} \mathrm{NaCl}, 30 \mathrm{mg} / \mathrm{L}$ $\mathrm{MgSO}_{4} \cdot 7 \mathrm{H}_{2} \mathrm{O}, 3 \mathrm{mg} / \mathrm{L} \mathrm{FeCl}_{3} \cdot 6 \mathrm{H}_{2} \mathrm{O}$, and $1 \mathrm{~g} / \mathrm{L}$ glucose, which is modified from Chen et al. [12]. All the media used were sterilized by autoclaving $\left(121^{\circ} \mathrm{C}, 1.1 \mathrm{~atm}\right.$, $15 \mathrm{~min}$.). Hydrogen chloride $(\mathrm{HCl})$ and sodium hydroxide $(\mathrm{NaOH})$ were used for $\mathrm{pH}$ adjustment. All chemicals used were of analytical grade and most of them were purchased from Fluka (Switzerland) or Sigma (USA). In addition, LAS was obtained from Lion Corporation Limited (Thailand).

\section{Surfactant determination:}

Critical micelle concentration (CMC) and standard curves were used. Stock solution of LAS ( $1 \mathrm{~g} / \mathrm{L}$ concentration) was diluted in Luria broth (LB) media and synthetic media to prepare LAS concentrations of $0,0.01,0.05,0.1,0.5$, and $1.0 \mathrm{~g} / \mathrm{L}$, respectively. The temperature was adjusted at $37^{\circ} \mathrm{C}$. The surface tension $(\mathrm{mN} / \mathrm{m})$ was measured by tensiometer (Tensiometer K6, KRÜSS de) and was plotted against the concentrations of the solution.

\section{Determination of the optimal conditions of AOS-15 to degrade LAS:}

The optimal conditions for LAS biodegradation by AOS-15 were studied. Firstly, the effect of the amount of cell mass, i.e., 0.6, 0.9, 1.2, 1.5, 1.8, 2.1 and 2.4 $\mathrm{g}$, suitable for biodegradation of synthetic wastewater was determined by using $100 \mathrm{~mL}$ synthetic media containing $3.0 \mathrm{~g} / \mathrm{L}$ LAS and pH7. Bacterial AOS-15 cell was cultured in Luria-Bertani (LB) media until the log phase, and then the cell was separated after centrifugation at $5000 \mathrm{~g}$ for 15 min. Moreover, LAS concentration suitable for the biodegradation of synthetic wastewater was determined by using concentrations of $1.5,3.0$ and $5.0 \mathrm{~g} / \mathrm{L}$ with $0.6 \mathrm{~g}$ wet cell at $\mathrm{pH} 7$. The effect of $\mathrm{pH}$ varied from 6-9 on using the $0.6 \mathrm{~g}$ wet cell at $\mathrm{pH} 7$. In all experiments, the amount of oxygen and temperature were controlled by the incubator shaker at $175 \mathrm{rpm}, 37^{\circ} \mathrm{C}$ for 48 hours. The sample was then precipitated by the centrifugal method and kept supernatant by diluting an amount equal to CMC concentration. The suspended and immobilized cells were compared in the three experiments for determining: 1) amount of cell mass 2) initial LAS concentration, and 3) $\mathrm{pH}$.

\section{Immobilized AOS-15 microorganism with calcium alginate gel:}

For immobilizing the microorganisms, 3\% (w/v) sodium alginate and 3\% (w/v) sodium carbonate were prepared and added into the bacterial AOS-15 cell, which was cultured in the LB media until the log phase. Then, the cell was separated by $5000 \mathrm{~g}$ centrifuge for 15 min. The mixture was then dropped into $4 \%$ (w/v) calcium chloride and incubated at $4{ }^{\circ} \mathrm{C}$ for one hour. The immobilized cells were washed with synthetic medium, which is modified from Chen et al. [12] and incubated at $37^{\circ} \mathrm{C}$ for two hours.

\section{Kinetic of LAS biodegradation in batch by using POLYMATH ${ }^{\mathrm{TM}}$ program:}

The results of section 2.3 were used to calculate the biodegradation rate, and predict the kinetic model of LAS degradation by using the POLYMATH ${ }^{\mathrm{TM}}$ program. The conditions were $1.5-5 \mathrm{~g} / \mathrm{L}$ LAS, $\mathrm{pH} 7$ and $2.1 \mathrm{~g}$ of cell in $100 \mathrm{ml}$ of LAS.

\section{Packed Bed Reactor (PBR) and conditions to study the LAS biodegradation in a continuous flow:}

Packed Bed Reactor (PBR) is a column of $1.9 \mathrm{~cm}$ diameter and $30 \mathrm{~cm}$ height, with a total volume of $85 \mathrm{ml}$. AOS-15 immobilized cells were placed inside this column. The media and surfactant can flow from the bottom to the top (Up-flow). Air was pumped into the reactor before the media and surfactant. A water jacket controlled and maintained the temperature of the reactor at $37^{\circ} \mathrm{C}$. The apparatus setup is presented in figure 1 . The performance of the PBR was studied by using $3 \mathrm{~g} / \mathrm{L}$ initial concentration of LAS, $\mathrm{pH} 7$, and $0.021 \mathrm{~g}$ cell $/ \mathrm{ml}$ of alginate. Initially, the synthetic medium was fully pumped into the column. Then, $3 \mathrm{~g} / \mathrm{L}$ LAS was pumped at $0.06 \mathrm{ml} / \mathrm{min}$ rate (retention time was 24 hours). After 24 hours, the first sample was collected to determine the remaining LAS, followed by subsequent collections after every 4 hours.

\section{Statistical Analysis:}

Each experiment was performed in triplicate. The data was found to be reproducible and the values reported in the figures were the average of the measurements. The data analyzed by the statistical tests using Microsoft Excel software. Statistical analysis consisted of summary statistics, including means, standard deviation and standard errors, where two-way analysis of variance was done, and then comparison was conducted at the 0.05 level.

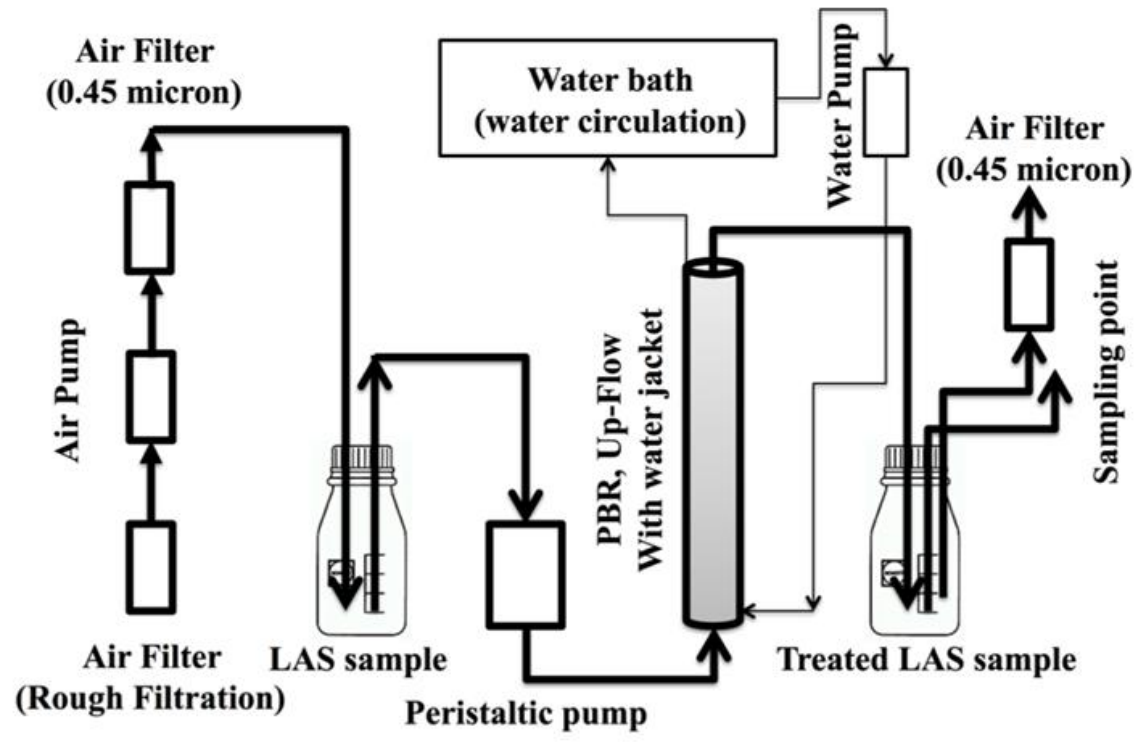

Fig. 1: Schematic representation of the Packed Bed Reactor (PBR).

\section{Results:}

Biodegradation of LAS surfactant using different microbial cells:

This experiment aimed to study the suitable amount of AOS- 15 cells needed to biodegrade $3 \mathrm{~g} / \mathrm{L}$ LAS. Wet cell volumes of 0.6, 0.9, 1.2, 1.5, 1.8, 2.1, and 2.4 g were used to biodegrade the initial LAS concentration of $3 \mathrm{~g} / \mathrm{L}, 100 \mathrm{ml}$ in $\mathrm{pH} 7$ for 48 hours. As shown in figure 2, on increasing the amount of cells, the degradation performance also increased, $2.1 \mathrm{~g}$ of cell showed $70.56 \%$ degradation. When the cell volume was increased to $2.4 \mathrm{~g}$, degradation slightly increased to $71.24 \%$. Thus, the cell volume of $2.1 \mathrm{~g}$ is the appropriate amount for LAS biodegradation. The suitable condition of AOS-15 free cell to biodegrade $3 \mathrm{~g} / \mathrm{L}$ LAS 
was $2.1 \mathrm{~g}$ cell mass. On the other hand, AOS-15 was rod-shaped aerobic gram-negative motile bacteria. From the results obtained using King B Medium selective media, this bacteria was identified as Pseudomonassp.. AOS-15 was further examined for colony and cell appearance, gram stain, catalase and oxidase activity.

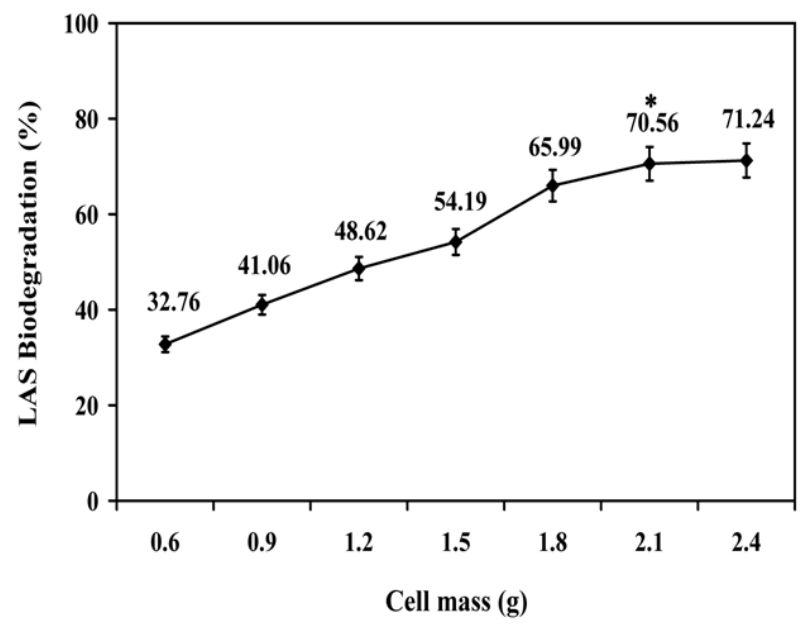

Fig. 2: Biodegradation rate of LAS by AOS-15 suspended cell at different cell mass in 48 hours.

Study of the parameters for LAS biodegradation by AOS-15 (Free and immobilized cells):

LAS biodegradation by using different LAS initial concentration:

The study on the ability of AOS-15 microorganism to biodegrade LAS at various initial LAS concentrations in cell free (Figure $3 \mathrm{~b}$ ) showed that at small amount of initial LAS concentration, AOS-15 microorganism biodegraded quickly. When the initial LAS concentration was increased, AOS-15 microorganism biodegraded rather slowly. The LAS biodegradation at LAS initial concentration $1.5,3$ and $5 \mathrm{~g} / \mathrm{L}$ were $72.5 \%, 71.6 \%$ and $46.31 \%$, respectively. So, $3 \mathrm{~g} / \mathrm{L}$ was the suitable initial LAS concentration for $2.1 \mathrm{~g}$ AOS-15 free cell to biodegrade $100 \mathrm{ml}$ LAS. On the other hand, the study on the ability of AOS-15 microorganism to biodegrade LAS at different initial LAS concentration in immobilized cell (Figure $3 \mathrm{~b}$ ) showed that the LAS concentration was almost removed at 48 hours at LAS concentrations 1.5 and $3 \mathrm{~g} / \mathrm{L}$ by $2.1 \mathrm{~g}$ of cell mass which were $99.87 \%$ and $99.79 \%$, respectively. Besides, $2.1 \mathrm{~g}$ of immobilized cell had the ability to degrade up to $5 \mathrm{~g} / \mathrm{L}$ of LAS which was $85.65 \%$. And $3 \mathrm{~g} / \mathrm{L}$ initial LAS concentration was selected to use for further study.
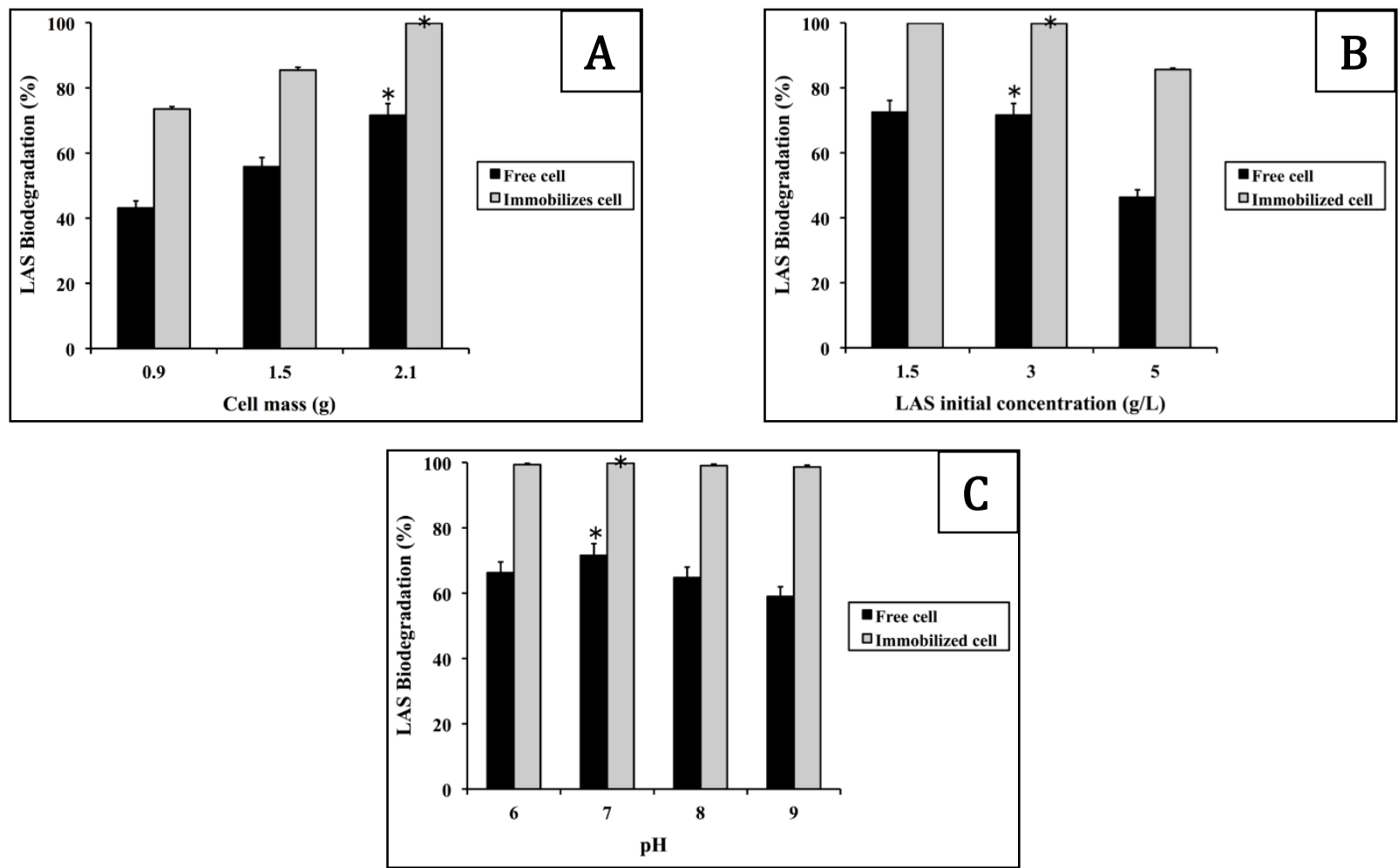

Fig. 3: Biodegradation rate of LAS by AOS-15 (free and immobilized cell) in 48 hours: a) at different cell mass, b) at different LAS initial concentrations, c) at different $\mathrm{pH}$.

LAS biodegradation by using different $\mathrm{pH}$ :

This experiment aimed to study the suitable $\mathrm{pH}$ to biodegrade $3 \mathrm{~g} / \mathrm{L}$ LAS. $\mathrm{pH} 6,7,8$ and 9 were used to test the biodegradation at the initial LAS concentration of $3 \mathrm{~g} / \mathrm{L}, 100 \mathrm{ml}$ by $2.1 \mathrm{~g}$ of cell mass. The effect of various initial $\mathrm{pH}$ of the cell free and immobilized AOS-15 during the batch fermentation of synthetic wastewater is illustrated in figure $3 \mathrm{c}$. The study of the ability of AOS-15 microorganism to biodegrade LAS at various pH in free cell showed that the LAS concentrations in all $\mathrm{pH}$ decreased at 48 hours. At pH6, pH7, $\mathrm{pH} 8$ and $\mathrm{pH} 9$, the LAS biodegradations in synthetic wastewater in 48 hours were $66.27 \%$, $71.60 \%, 64.80 \%$ and $59.02 \%$, respectively. When comparing the LAS concentrations of all the experiments, $\mathrm{pH} 7 \mathrm{condition}$ was found to be the most suitable $\mathrm{pH}$. On the other hand, the study of the ability of AOS-15 microorganism to biodegrade LAS at various pH in immobilized cell showed that the LAS biodegradation in pH6, 7,8 and 9 were $99.35 \%, 99.79 \%, 99.04 \%$ and $98.67 \%$, respectively. This result showed that the nitrate concentration was almost removed at 48 hours. When 
comparing the LAS concentrations in immobilization experiments, it was concluded that all $\mathrm{pH}$ conditions were suitable to be used for LAS biodegradation, as the immobilized technique would protect the cell from the unsuitable $\mathrm{pH}$. And $\mathrm{pH} 7$ was selected to use for further study because of the highest LAS biodegradation.

Model for the kinetics of biodegradation of substrates in batch by POLYMATH ${ }^{T M}$ :

Table. 1 shows the rate at which microorganisms biodegraded LAS by using initial concentrations of $1.5,3$, and $5 \mathrm{~g} / \mathrm{L}$ after 48 hours. The simulation of kinetic regression by using POLYMATH ${ }^{\mathrm{TM}}$ program was used for the prediction. It showed the relation between results from the experiment and theoretical factors of kinetic simulation. Thus, we got the simulation, which is specific to this experiment, and can be used to design bioreactors in the near future. Besides, the kinetic model used in this study is given in equation (1).

Table 1: Biodegradation rate of LAS by AOS-15 in batch.

\begin{tabular}{|l|l|}
\hline LAS concentration $(\mathbf{g} / \mathbf{l})$ & Biodegradation rate $\left(\mathbf{g} . \mathbf{L} .{ }^{-1} \mathbf{h}^{-1}\right)$ \\
\hline 1.5 & 0.0344 \\
\hline 3 & 0.0229 \\
\hline 5 & 0.0077 \\
\hline
\end{tabular}

$-r s=\frac{-r s, \max S}{K s+S}$

where,

$-\mathrm{r}_{\mathrm{s}}$ is the biodegradation rate of LAS $(\mathrm{g} / \mathrm{L} \cdot \mathrm{hour})$

$-r_{s, \max }$ is the biodegradation rate of LAS (maximum) $(\mathrm{g} / \mathrm{L} \cdot \mathrm{hour})$

Sis the LAS concentration $(\mathrm{g} / \mathrm{L})$

$\mathrm{K}_{\mathrm{s}}$ is the concentration that leads to half-maximal velocity $(\mathrm{g} / \mathrm{L})$

The kinetic model in equation (1) is adapted from Monod's model, which is considered in terms of LAS degradation in which the toxicity of substrate inhibits bacterial growth [13].

The results showed the kinetic model given in equation (2)

$$
-r_{s}=\frac{0.0540 \mathrm{~s}}{4.0299 \mathrm{~s}}
$$

$\mathrm{R}$ square, R2, of equation (2) is 0.80 . So, equation (2) is the kinetic model of biodegradation of LAS by AOS-15 microorganisms (Batch, LAS concentration from $1.5-5 \mathrm{~g} / \mathrm{L}, \mathrm{pH} 7$ and $2.1 \mathrm{~g}$ of cell in $100 \mathrm{ml}$ of LAS).

Packed Bed Reactor (PBR) to degrade LAS surfactant in a continuous flow system:

Wastewater treatment by microbe is a cheap and efficient method to remove contaminants. However, its disadvantages include the loss of cells used in the decomposition and the cost of cell culture. The immobilized cell method could be used to solve these problems. Besides, the Packed Bed Reactor (PBR) system can be variedly used. Research exists on the treatment of wastewater, contaminated with acetonitrile, using a PBR with microorganisms inside its column. The PBR was created with three main components: (i) the aeration system to substrate, (ii) the reactor system, and (iii) the temperature control system. The details are given in Figure 4.

In this experiment, AOS-15 immobilized microorganisms were used in PBR to increase the efficiency of the biodegradation, and to reduce the steps to reculture the microbe. The immobilized microorganism was placed in the PBR column and the synthetic medium was added to the cell culture. LAS was pumped into it at $0.06 \mathrm{ml} /$ minute, which equals the retention time of 24 hours. The resultant solution was then evaluated, as shown in Figure 5. Figure 5. shows that at 0 hour (the reactor was run 24 hours already), the LAS concentration measured at $0.01 \mathrm{~g} / \mathrm{L}$ showed the highest performance ( $96.80 \%$ biodegradable). Besides, the reactor showed high performance (higher than $80 \%$ biodegradable) till 48 hours (the reactor was run 72 hours already). However, the performance decreased after 60 hours (the reactor was run 84 hours already) and the LAS concentration reduced to $0.69 \mathrm{~g} / \mathrm{L}$ with a performance of $77.56 \%$. Moreover, the performance substantially decreased after 80 hours (the reactor was run 104 hours already) to $59.23 \%$ at $1.26 \mathrm{~g} / \mathrm{L}$ LAS concentration.

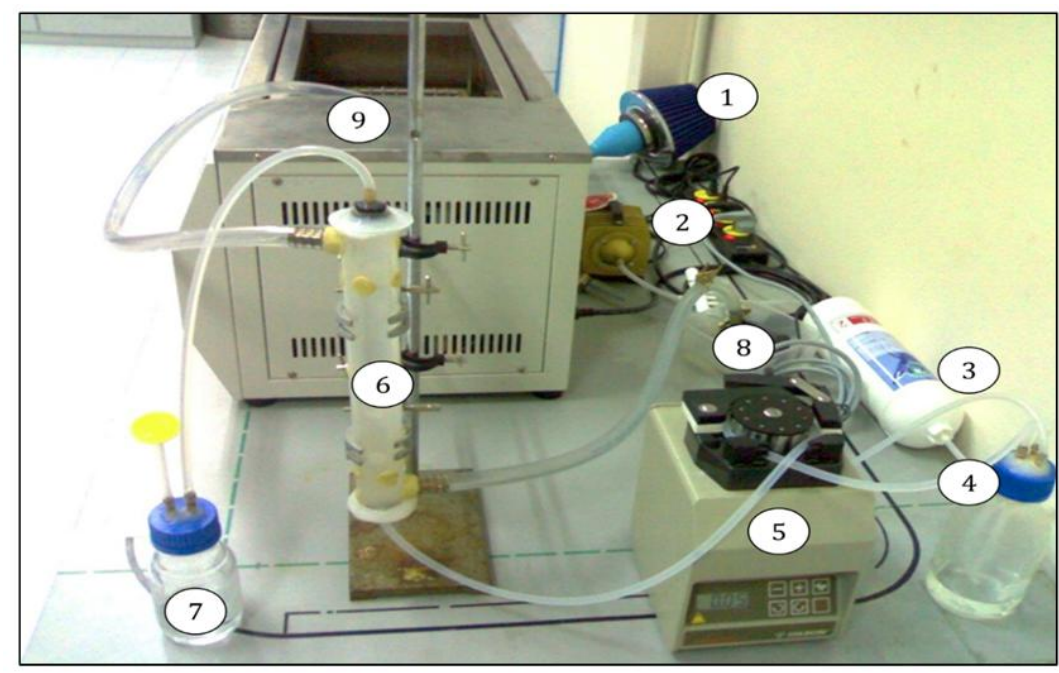

Fig. 4: PBR system to degrade LAS. (1): Air Filter (Rough filtration) (2): Air pump (3): Air filter (0.45 $\mu \mathrm{m}$ fine filtration) (4): LAS sample (5): Peristaltic pump (6): PBR,Up-flow volume $85 \mathrm{ml}$, water jacket (7): Treated LAS sample (8): Water pump (circulate water from water bath to water jacket) (9): Water bath. 


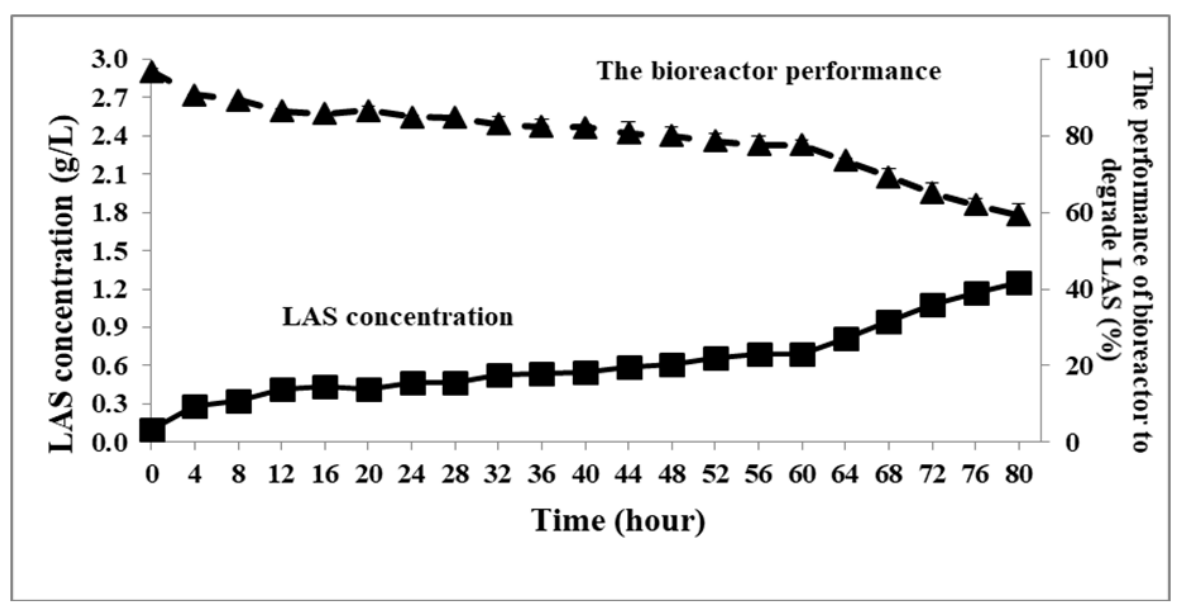

Fig. 5: LAS biodegradation by AOS-15 in PBR system.

Discussion:

Among the technologies available for the treatment of wastewaters containing organic compounds, biological treatments is one of the most advantageous due to its relatively low cost in comparison to physicochemical treatments. Scott and Jones[14] studied that aerobic microorganisms can degrade the surfactant. Some microorganisms probably oxidize the alkyl chain while others participate in the mineralization of the aromatic chain. Jangiam et al. [5] studied the protein sequence alignment of enzymes and reported that Pseudomonas putida has high potential to degrade anionic surfactants.

We studied the biodegradation of LAS by using AOS-15 microorganisms, which were cell free and in an immobilized condition. Our study found that the more cell mass, the more degradation rate is. The suitable cell mass is $2.1 \mathrm{~g}$ per $100 \mathrm{ml}$ LAS due to its highest biodegradation rate (70.56\%). This is in agreement with many studies $[13,15]$, which showed that the biodegradation rate increased with the increase in cell mass. Moreover, in our experiment, we found that on adding more cell mass, a small amount of change in the biodegradation rate occurred, with more time and increased cost requirement to prepare more cells. Hence, the suitable cell mass of our study was concluded at $2.1 \mathrm{~g}$ per $100 \mathrm{ml}$ LAS.

The study of the parameters for LAS biodegradation using various initial LAS concentrations showed that when initial LAS concentration increased, the biodegradation rate decreased. This was similar to the research of Abboud et al. [16], in which they explained that when LAS concentration increased, the toxicity of LAS to microorganisms also enhanced. Our results showed that the initial LAS concentration of $3 \mathrm{~g} / \mathrm{L}$ is the most suitable for LAS biodegradation at a rate of 70.56\%. This result is similar to the study of Khleifat [7], in which he studied the LAS biodegradation by Pantoeaagglomerans and Serratia odorifera. He found that LAS $200 \mathrm{ppm}$ was the most suitable condition with a degradation rate of $68 \%$ in 96 hours.

Our findings also showed that LAS biodegradation occurred in various $\mathrm{pH}$ (from 6-9), and $\mathrm{pH} 7$ was the most powerful condition with a degradation rate of 66.27\%. This was similar to the study of Lijun et al. [12], in which they studied the LAS biodegradation by Pseudomanasaeruginosa, and found that the suitable $\mathrm{pH}$ was in the range of 6-10. Culture medium $\mathrm{pH}$ can affect microbial diversity and activity and therefore make the effect of transport processes, nutrient solubility and enzyme activity [17]. Subsequently, LAS biodegradation at a range of culture medium $\mathrm{pH}$ values (pH 6-9) for both free and immobilized cells were analyzed. As shown in Figure 3c, the LAS biodegradation in 48 hours using free cell significantly increased from $66.27 \%$ to $71.60 \%$ when the $\mathrm{pH}$ of the culture medium ranged from 6 to 7 . As the $\mathrm{pH}$ value increased to 8 and 9, the LAS biodegradation for free cells declined from $71.60 \%$ to $64.80 \%$ and $59.02 \%$, respectively. These results are consistent with most studies, where microorganisms favored growth at $\mathrm{pH}$ ranging from 6.0 to 8.0 [17]. The research of Chen et al. (2007) [12],which studied the biodegradation of Phenol by Pseudomonas putida showed that the highest biodegradation rate was found in $\mathrm{pH} 7$. It is likely that such acidic or alkaline conditions affect the activity of organisms. However, the performance of LAS biodegradation of AOS-15 in cell suspension and immobilized cell was compared, it showed that the LAS biodegradation of AOS-15 in immobilized cell at various $\mathrm{pH}$ had high performance than in cell suspension (Figure 3c). It was therefore demonstrated that LAS biodegradation using immobilized cells was less sensitive to the medium $\mathrm{pH}$ changes. This result was in agreement with the study of Chen et al. [13], who immobilized Klebsiella oxytoca to treat wastewater containing cyanide, and found that $K$. oxytoca could biodegrade at $\mathrm{pH}$. They also found that the immobilized cell performed more than the cell suspension. Moreover, this is in agreement with Lijun et al. [6], which studied the LAS biodegradation by $P$. aeruginosa and showed that the immobilized cell had a higher biodegradation rate than the suspended cell. Thus, immobilized carrier protected cells, it was good for keeping the stable $\mathrm{pH}$ value inside bacteria, avoiding acidification of microorganism[18].

The model for the kinetics of biodegradation of substrate in batch was: $-r_{s}=\frac{0.0540 \mathrm{~s}}{4.0299 \mathrm{~s}}$. This kinetic model explained the relation between the LAS biodegradation rate and concentration of LAS under experimented concentration (Batch, LAS concentration from $1.5-5 \mathrm{~g} / \mathrm{L}$, pH7 and $2.1 \mathrm{~g}$ of cell in $100 \mathrm{ml}$ of LAS). In fact, we can use this kinetic model to design a bigger bioreactor to degrade LAS. The LAS biodegradation by AOS-15 microorganisms in a continuous flow system of PBR showed the efficiency of biodegradation. The results suggest that the study of various flow rate should be considered as the study of cyanidecontaining water and the flow rate was set to $1.5 \mathrm{ml} \mathrm{h}^{-1}$, complete degradation of $12 \mathrm{mmol} \mathrm{l}^{-1}$ cyanide in 10 hours was observed [19]. Our experiment showed that the PBR system had a high efficiency of LAS degradation, i.e., in $0-84 \mathrm{~h}$, the biodegradation rate ranged from $80-96 \%$.

5. Conclusion and Future Work

1. The suitable cell mass of AOS-15 that could degrade LAS was $2.1 \mathrm{~g}$ per LAS $100 \mathrm{ml}$, which had $70.56 \%$ degradation.

2. The initial LAS concentration suitable for LAS degradation by AOS-15 was $3 \mathrm{~g} / \mathrm{L}$, which had $70.56 \%$ degradation.

3. The suitable $\mathrm{pH}$ to degrade LAS by AOS-15 was $\mathrm{pH} 7$, which had $70.56 \%$ degradation.

4. The model for the kinetics of biodegradation of substrate in batch was $-r_{s}=\frac{0.0540 \mathrm{~s}}{4.0299 \mathrm{~s}}$

5. Our experiment showed that PBR, which had AOS-15 microorganisms in a continuous flow system, had the highest efficiency to degrade LAS. In 0-84 hours, the biodegradation rate ranged from $80-96 \%$.

The study reveals the potential of cells entrapped in calcium alginate beads system for biodegradation of LAS, although, the current study serves as a pertinent example that further extensive researches are required such as regenerated immobilized cells for extended long-time degradation also can be scaled up and employed for remediation of LAS at larger scale.

\section{ACKNOWLEDGEMENT}

This work was supported in part by a research grant (contract number 13/2553) from the Faculty of Engineering, Burapha University. The LAS requirement was supported by Lion Corporation Limited (Thailand). 


\section{REFERENCES}

[1] Dehghani, M.H., A.A. Najafpoor, K. Azam, 2010. Using sonochemical reactor for degradation of LAS from effluent of wastewater treatment plant. Desalination, 250(1): 82-86.

[2] Ying, G.G., 2006. Fate, behavior and effects of surfactants and their degradation products in the environment. Environment International, $32: 417-431$.

[3] Mungray, A.K., P. Kumar, 2009. Fate of linear alkylbenzene sulfonates in the environment: A review. International Biodeterioration and Biodegradation, 63(8): 981-987.

[4] de Oliveira, L.L., I.C. Silveira Duarte, I.K. Sakamoto, M.B. Amâncio Varesche, 2009. Influence of support material on the immobilization of biomass for the degradation of linear alkylbenzene sulfonate in anaerobic reactors. Journal of Environmental Management, 90(2): 1261-1268.

[5] Jangiam, W., K. Oum-in, O. Thongnoppakun, 2010. The selection of bacterial consortium for the biodegradation of sodium dodecyl sulfate and linear alkylbenzene sulfonate. Journal of Science, Technology and Humanities, 8(1): 25-32.

[6] Lijun, X., W. Bochu, Z. Li, D. Chuanren, W. Qinghong, L. Liu, 2005. Linear alkyl benzene sulphonate (LAS) degradation by immobilized Pseudomonas aeruginosa under low intensity ultrasound. Colloids and Surfaces B: Biointerfaces, 40(1): 25-29.

[7] Khleifat, K.M., 2006. Biodegradation of linear alkylbenzene sulfonate by a two-member facultative anaerobic bacterial consortium. Enzyme and Microbial Technology, 39(5): 1030-1035.

[8] de Oliveira, L.L., R.B. Costa, D.Y. Okada, D.V. Vich, I.C.S. Duarte, E.L. Silva, M.B.A. Varesche, 2010. Anaerobic degradation of linear alkylbenzene sulfonate (LAS) in fluidized bed reactor by microbial consortia in different support materials. Bioresource Technology, 101(14): 5112-5122.

[9] Bergero, M.F., A.S. Liffourrena, B.A. Opizzo, A.S. Fochesatto, G.I. Lucchesi, 2017. Immobilization of a microbial consortium on Ca-alginate enhances degradation of cationic surfactants in flasks and bioreactor. International Biodeterioration \& Biodegradation, 117: 39-44.

[10] Cheng, Z., Y. Wei, Q. Zhang, J. Zhang, T. Lu, Y. Pei, 2018. Enhancement of surfactant biodegradation with an aerobic membrane bioreactor by introducing microaeration. Chemosphere, 208: 343-351.

[11] Merkova, M., M. Zalesak, E. Ringlova, M. Julinova, J. Ruzicka, 2018. Degradation of the serfactant Cocamidopropyl betaine by two bacterial strains isolated from activated sludge. International Biodeterioration \& Biodegradation, 127: 236-240.

[12] Chen, Y.M., T.F. Lin, C. Huang, J.C. Lin, F.M. Hsieh, 2007. Degradation of phenol and TCE using suspended and chitosan-bead immobilized Pseudomonas putida. Journal of Hazardous Materials, 148(3): 660-670.

[13] Chen, C.Y., S.C. Chen, M. Fingas, C.M. Kao, 2010. Biodegradation of propionitrile by Klebsiella oxytoca immobilized in alginate and cellulose triacetate gel. Journal of Hazardous Materials, 177(1-3): 856-863.

[14] Scott, M.J., M.N. Jones, 2000. The biodegradation of surfactants in the environment. Biochimica et Biophysica Acta - Biomembranes, 1508(1-2): 235-251.

[15] Chen, C.Y., C.M. Kao, S.C. Chen, 2008. Application of Klebsiella oxytoca immobilized cells on the treatment of cyanide wastewater. Chemosphere. 71(1): 133-139.

[16] Abboud, M.M., K.M. Khleifat, M. Batarseh, K.A. Tarawneh, A. Al-Mustafa, M. Al-Madadhah, 2007. Different optimization conditions required for enhancing the biodegradation of linear alkylbenzosulfonate and sodium dodecyl sulfate surfactants by novel consortium of Acinetobacter calcoaceticus and Pantoea agglomerans. Enzyme and Microbial Technology, 41(4): 432-439.

[17] Lin, , L. Gan, Z.L. Chen, 2010. Biodegradation of naphthalene by strain Bacillus fusiformis (BFN). Journal of Hazardous Materials, 182(1-3): 771-777.

[18] Zheng, C., J. Zhou, J. Wang, B. Qu, J. Wang, H. Lu, H. Zhao, 2009. Aerobic degradation of nitrobenzene by immobilization of Rhodotorula mucilaginosa in polyurethane foam. Journal of Hazardous Materials, 168(1): 298-303.

[19] Kumar, V., V. Kumar, T.C. Bhalla, 2015. Packed bed reactor for degradation of simulated cyanide-containing wastewater. 3 Biotech., 5: 641-646. 